\title{
Tanier Corms as Feed for Growing Pigs ${ }^{1,2}$
}

\author{
Manuel Soldevila and José Vicente-Chandler ${ }^{3}$
}

\begin{abstract}
Tanier corms, a rarely used byproduct of tanier production, were evaluated as a feed source for pigs in combination with various levels of concentrate. Tanier corms contained about $20 \%$ dry matter, and 20 to $30 \%$ of the corms were lost during peeling. Peeled corms were stored frozen in plastic bags for long periods but spoiled within a day after thawing.

Peeled corms were not as palatable as boiled, unpeeled corms. Pigs refused to eat unpeeled, unboiled corms. Pigs receiving only concentrated feed had the best weight gains, and those receiving only corms had almost no weight gains. Pigs receiving 30 to $48 \%$ of their ration as tanier corms, complemented with a 16- or a $24 \%$-protein concentrate containing double quantity of vitamins, trace elements, and salt, had growth rates and feed efficiencies only 10 to $20 \%$ less than those fed a full concentrate ration. The main limitation in feeding corms at rates greater than 30 to $48 \%$ of the total ration seems to be the impossibility of the animal's ingesting enough dry matter (due to the high moisture content of the corms) to meet the requirements of maximum growth.
\end{abstract}

\section{INTRODUCTION}

A search of literature $(4,6,7)$ showed no scientific studies to determine the value of tanier corms as an ingredient in swine rations.

Taniers are an important food crop throughout much of the humid tropics. In Puerto Rico about 2,000 ha/yr are planted, mostly in small fields in the mountain region. The average yields are 7.4 metric tons/ha of tubers for human consumption and 7.4 metric tons/ha of corms (2). Yields of 24.7 metric tons/ha/yr of tubers and 24.7 metric tons/ha/yr of corms are produced by intensively cultivated taniers. Tanier corms are planted as a supplementary material $(10-20 \%$ of the tanier mix) in preparing pasteles, but most are simply discarded or fed to pigs. Unpeeled corms can be stored for as long as a year with no special care.

The purpose of this study was to determine the amount of tanier corms that can be efficiently utilized in the feed ration of growing pigs.

\section{MATERIALS AND METHODS}

Samples of tanier corms and of the other feed ingredients were analyzed and the data used to develop recommended feed formulations $(1,3,5)$. Raw tanier corms contain about $20 \%$ dry matter, of which $4.5 \%$ is crude

${ }^{1}$ Manuscript submitted to Editorial Board April 4, 1977.

${ }^{2}$ Research conducted jointly by the Agricultural Research Service, USDA, and the Agricultural Experiment Station of the Mayagüez Campus of the University of Puerto Rico.

${ }^{3}$ Investigator in Animal Nutrition, Agricultural Experiment Station, Mayagüez Campus, University of Puerto Rico, and Soil Scientist-Location Leader, A. R. S., USDA, Río Piedras, P.R. The authors express their appreciation to Ismael Carlo and Jorge Bauermeister for their technical help. 
protein, $1.1 \%$ is ash, $0.1 \%$ is reducing sugars, and $0.4 \%$ is inverted sugars. The difference (about 13.9\%) is assumed to be starch.

Experiment No. 1. lasted 4 weeks and compared the following diets: Raw mechanically-peeled tanier corms fed ad libitum; raw mechanicallypeeled corms fed ad libitum plus $0.9 \mathrm{~kg}$ of $16 \%$-crude-protein concentrate daily; raw mechanically-peeled corms fed ad libitum plus $0.9 \mathrm{~kg}$ of $24 \%$ crude-protein concentrate daily; raw chemically-peeled corms (skin removed with a $15 \%$ sodium hydroxide solution $)^{4}$ fed ad libitum plus $0.9 \mathrm{~kg}$ of $16 \%$-crude-protein concentrate daily.

Three females and two barrows of different crosses, weighing about 9 $\mathrm{kg}$ each, were fed at random each of the four treatments.

Experiment No. 2, which lasted 3 weeks, utilized the following treatments: raw mechanically-peeled tanier corms fed ad libitum; raw mechanically-peeled corms fed ad libitum plus $0.9 \mathrm{~kg}$ of $16 \%$-crude-protein concentrate daily; boiled unpeeled corms fed ad libitum plus $0.9 \mathrm{~kg}$ of $16 \%$-crude-protein concentrate daily; $1.8 \mathrm{~kg}$ of $16 \%$-crude-protein concentrate fed daily.

Four females and four barrows of different crosses, weighing about 16 $\mathrm{kg}$, were assigned at random to each of the four treatments.

Experiment No. 3 employed the following treatments and lasted 8 weeks: 16\%-crude-protein concentrate fed ad libitum; raw chemicallypeeled corms fed at the rate of $15 \%$ of the ration ${ }^{5}$; raw chemically-peeled, corms fed at the rate of $30 \%$ of the ration ${ }^{5}$.

Five barrows of different crosses, initially weighing about $36 \mathrm{~kg}$, were fed at random each of the three treatments.

In all studies the pigs were weighed weekly and the weight of corms and feed consumed was recorded. All data on weight gain and feed consumption were analyzed statistically (9).

\section{RESULTS AND CONCLUSIONS}

About 7 days were required before pigs became fully accustomed to consuming raw peeled tanier corms; however, consumption increased gradually.

Table 1 shows that pigs fed a diet consisting only of raw, peeled tanier corms made almost no net gain $(0.9 \mathrm{~kg} / \mathrm{pig})$ during the 4 -week period. However, when the taniers were supplemented with either a 16 or $24 \%$ crude protein concentrate (containing twice the ordinary concentration of vitamins, trace elements, and salt to compensate for a possible lack of these elements in the tanier corms), they gained 5.0 and $5.8 \mathrm{~kg} / \mathrm{pig}$ for the 16 and $24 \%$ protein concentrate, respectively. However, weight gained

\footnotetext{
${ }^{4}$ Following the method described under (8).

${ }^{5}$ Remainder of ration was made up of $16 \%$ crude protein concentrate.
} 
by the pigs fed chemically-peeled corms ( $15 \%$ sodium hydroxide solution) was only $3.3 \mathrm{~kg}$. The lower gains made by pigs fed chemically-peeled corms can probably be explained by corm decomposition soon after thawing. These corms were treated in large batches and frozen and then thawed before being fed, whereas mechanically peeled corms were fed soon after peeling. Frozen corms decomposed markedly if not consumed within 24 hours after thawing. With all four treatments, growth rates of pigs were below optimum.

TABLE 1. - Weight gains after 4 weeks from Guavate Penal Facility pigs (3 females and 2 barrows) fed raw tanier corms ad libitum with and without supplementary material in experiment no. $1^{1,2}$

\begin{tabular}{|c|c|c|c|c|c|}
\hline \multirow{2}{*}{$\begin{array}{l}\text { Diet } \\
\text { no. }\end{array}$} & \multirow{2}{*}{ Diet description } & \multicolumn{2}{|c|}{$\begin{array}{l}\text { Average weight, pounds } \\
(\mathrm{kg}) / \mathrm{pig}\end{array}$} & \multirow{2}{*}{$\begin{array}{l}\text { Net } \\
\text { gain }\end{array}$} & \multirow{2}{*}{$\begin{array}{l}\text { Daily } \\
\text { gain }\end{array}$} \\
\hline & & Initial & Final & & \\
\hline 1 & $\begin{array}{l}\text { Mechanically-peeled } \\
\text { corms }\end{array}$ & $17.4(7.9)$ & $19.3(8.8)$ & $1.9(0.9) \mathrm{a}^{1}$ & $0.07(0.03)$ \\
\hline 2 & $\begin{array}{l}\text { Mechanically-peeled } \\
\text { corms + } 0.9 \mathrm{~kg} \\
16 \% \text {-crude-protein } \\
\text { concentrate daily }\end{array}$ & $16.4(7.5)$ & $27.3(12.4)$ & $10.9(4.9) \mathrm{b}$ & $.39(0.18)$ \\
\hline 3 & $\begin{array}{l}\text { Mechanically-peeled } \\
\text { corms }+0.9 \mathrm{~kg} \\
24 \% \text {-crude-protein } \\
\text { concentrate daily }\end{array}$ & $18.0(8.2)$ & $30.8(14.0)$ & $12.8(5.8) b$ & $.46(0.21)$ \\
\hline 4 & $\begin{array}{l}\text { Chemically-peeled } \\
\text { corms + } 0.9 \mathrm{~kg} \\
16 \% \text {-crude-protein } \\
\text { concentrate daily }\end{array}$ & $17.4(7.9)$ & 24.7 (11.2) & $7.3(3.3) \mathrm{ab}$ & $.26(0.12)$ \\
\hline
\end{tabular}

${ }^{1}$ Column means followed by one or more letters in common do not differ significantly at the $\mathrm{P}=.05$ level.

${ }^{2}$ The raw tanier corms contained about $20 \%$ dry matter. The chemical content (as fed) was $4.5 \%$ crude protein, $1.1 \%$ ash, $0.1 \%$ reducing sugars, and $0.4 \%$ total inverted sugars. The difference (about 13.9\%) is assumed to be starch. When tanier corms were peeled mechanically (machete, knife) the yield was $79 \%$, and when they were peeled chemically (15\% solution of $\mathrm{NaOH}$ ), yield was $71 \%$.

Table 2 shows that, as in experiment no. 1, pigs fed exclusively raw mechanically-peeled, tanier corms had almost no weight gains. However, pigs fed raw peeled corms or boiled unpeeled corms, supplemented with $0.9 \mathrm{~kg}$ of $16 \%$-crude-protein concentrate daily, had similar daily gains. They averaged over $0.45 \mathrm{~kg} /$ day as compared with $0.64 \mathrm{~kg}$ /day gained by pigs fed $1.8 \mathrm{~kg}$ of $16 \%$-crude-protein concentrate daily. The pigs readily accepted the boiled unpeeled corms, but they required about 7 days before they became fully accustomed to the raw peeled corms.

Table 3 shows that pigs fed a 16\%-crude-protein concentrate ad libitum 
TABLE 2.-Weight gains, feed consumption and utilization after 3 weeks from Guavate Penal Facility pigs (4 females and 4 barrows) fed raw and boiled tanier corms ad libitum and/or a 16\%-protein concentrate in experiment no. $2^{1}$

\begin{tabular}{|c|c|c|c|c|c|c|c|c|c|}
\hline \multirow{2}{*}{$\begin{array}{l}\text { Diet } \\
\text { no. }\end{array}$} & \multirow{2}{*}{ Description } & \multicolumn{3}{|c|}{ Average weight, pounds $(\mathrm{kg}) / \mathrm{pig}$} & \multirow{2}{*}{ Daily gain } & \multicolumn{3}{|c|}{ Net consumption, pounds $(\mathrm{kg}) / \mathrm{pig}$} & \multirow{2}{*}{$\begin{array}{l}\text { Efficiency } \\
\text { of feed } \\
\text { utilization }\end{array}$} \\
\hline & & Initial & Final & Net gain & & Corms $^{2}$ & Concentrate & Total $^{3}$ & \\
\hline & & & & & & & & & $\begin{array}{l}\text { Gain/con- } \\
\text { sumption }\end{array}$ \\
\hline 1 & $\begin{array}{l}\text { Raw, mechanically- } \\
\text { peeled corms }\end{array}$ & $36.8(16.7)$ & $37.3(17.0)$ & $0.5(0.3) \mathrm{a}$ & $0.02(0.01)$ & $34.0(15.5)$ & - & $34.0(15.5)$ & 68.0 \\
\hline 2 & $\begin{array}{l}\text { Raw, mechanically- } \\
\text { peeled corms }+ \\
0.9 \mathrm{~kg} 16 \% \text {-crude- } \\
\text { protein concen- } \\
\text { trate daily }\end{array}$ & $33.8(15.4)$ & $56.3(25.6)$ & $22.5(10.2) \mathrm{b}$ & $1.07(0.49)$ & $26.3(12.0)$ & $42.0(19.1)$ & $68.3(31.0)$ & 3.0 \\
\hline 3 & $\begin{array}{l}\text { Boiled, unpeeled } \\
\text { corms }+0.9 \mathrm{~kg} \\
16 \% \text {-crude-pro- } \\
\text { tein concentrate } \\
\text { daily }\end{array}$ & $31.6(14.4)$ & $56.3(25.6)$ & $24.7(11.2) \mathrm{b}$ & $1.17(0.53)$ & $38.2(17.4)$ & $42.0(19.1)$ & $80.2(36.5)$ & 3.3 \\
\hline 4 & $\begin{array}{l}1.8 \mathrm{~kg} 16 \% \text {-crude- } \\
\text { protein concen- } \\
\text { trate daily }\end{array}$ & $35.2(16.0)$ & $64.9(29.5)$ & $29.7(13.5) \mathrm{c}$ & $1.41(0.64)$ & - & $82.5(37.5)$ & $82.5(37.5)$ & 2.8 \\
\hline
\end{tabular}

${ }^{1}$ Column means followed by one or more letters in common do not differ significantly at the $\mathrm{P}=.05$ level.

${ }^{2}$ Adjusted to $90 \%$ dry matter. The raw tanier corms contained about $20 \%$ dry matter. The chemical content (as fed) was $4.5 \%$ crude protein, $1.1 \%$ ash, $0.1 \%$ reducing sugars and $0.4 \%$ total inverted sugars. The difference (approximately $13.9 \%$ ) was assumed to be starch.

${ }^{3}$ The total was calculated by adding the amount of concentrate plus the amount of tanier corms consumed adjusted to $90 \%$ dry basis.

${ }^{4}$ Based on consumption data adjusted to $90 \%$ dry basis. 
TABLE 3.-Weight gains, feed consumption, and utilization after 8 weeks from Lajas Substation barrows fed a 16\%-protein concentrate with and without chemically-peeled raw tanier corms in experiment no. $3^{\prime}$

\begin{tabular}{|c|c|c|c|c|c|c|c|c|c|}
\hline \multirow{2}{*}{$\begin{array}{l}\text { Diet } \\
\text { no. }\end{array}$} & \multirow{2}{*}{ Description } & \multicolumn{4}{|c|}{ Average weight, pounds $(\mathrm{kg}) / \mathrm{pig}$} & \multicolumn{3}{|c|}{ Net consumption, pounds $(\mathrm{kg}) / \mathrm{pig}$} & \multirow{2}{*}{$\begin{array}{l}\text { Efficiency } \\
\text { of feed } \\
\text { utilization }\end{array}$} \\
\hline & & Initial & Final & Net gain & Daily gain & Corms ${ }^{2}$ & Concentrate & Total $^{3}$ & \\
\hline & & & & & & & & & $\begin{array}{l}\text { Gain/con- } \\
\text { sumption }\end{array}$ \\
\hline 1 & $\begin{array}{l}\text { 16\%-crude- } \\
\text { protein con- } \\
\text { centrate }\end{array}$ & $79.2(36.0)$ & $174.8(79.5)$ & $95.6(43.5) \mathrm{a}$ & $1.71(0.77)$ & - & $452.5(205.7)$ & $452.5(205.7)$ & 4.73 \\
\hline 2 & $\begin{array}{l}\text { Raw, chemi- } \\
\text { cally-peeled } \\
\text { corms + } \\
16 \% \text {-crude- } \\
\text { protein con- } \\
\text { centrate } \\
\text { supplying } \\
\text { the remain- } \\
\text { der }\end{array}$ & $81.6(37.1)$ & $163.2(74.2)$ & $81.6(37.1) b$ & $1.46(0.66)$ & $64.3(29.2)$ & $377.0(171.4)$ & $441.3(200.6)$ & 5.41 \\
\hline 3 & $\begin{array}{l}\text { Raw, chemi- } \\
\text { cally-peeled } \\
\text { corms to } \\
\text { supply } 30 \% \\
\text { of the ration } \\
+16 \% \text { - } \\
\text { crude- pro- } \\
\text { tein concen- } \\
\text { trate }{ }^{5} \text { sup- } \\
\text { plying the } \\
\text { remainder }\end{array}$ & $82.6(37.5)$ & $164.8(74.9)$ & $82.2(37.4) \mathrm{b}$ & $1.47(0.67)$ & $123.3(56.0)$ & $280.3(127.4)$ & $403.6(183.4)$ & 4.99 \\
\hline
\end{tabular}

${ }^{1}$ Column means followed by one or more letters in common do not differ significantly at the $\mathrm{P}=.05$ level.

${ }^{2}$ Adjusted to $90 \%$ dry matter. The raw tanier corms contained about $21.5 \%$ dry matter. The chemical content (as fed) was $4.8 \%$ crude protein, $1.2 \%$ ash, $0.2 \%$ reducing sugars and $0.4 \%$ total inverted sugars. The difference (about $14.9 \%$ ) was assumed to be starch.

${ }^{3}$ The total was calculated by adding the amount of concentrate plus the amount of tanier corms consumed adjusted to $90 \%$ dry basis.

${ }^{4}$ Based on consumption data adjusted to $90 \%$ dry basis.

${ }^{5}$ This $16 \%$ crude-protein supplement contained $2 \times$ concentration of vitamins, trace elements, and $\mathrm{NaCl}$, as compared with the basal diet offered to the group consuming diet no. 1. 
gained an average of $0.8 \mathrm{~kg} / \mathrm{pig} /$ day. However, pigs fed either 15 or $30 \%$ of their ration as raw chemically-peeled corms complemented by a $16 \%$ crude-protein concentrate had almost identical weight gains, averaging $0.7 \mathrm{~kg} / \mathrm{pig} /$ day.

The larger pigs used in study No. 3 had better weight gains than those used in experiments No. 1 and 2. The growth trend resembled that in Experiment No. 2, where smaller pigs were used with corms supplying a large proportion (38-48\%) of the ration.

Probably larger pigs can be induced to consume more corms with less concentrate. However, the high moisture content of corms limits the amount that pigs can consume daily and, therefore, their gains.

Although pigs fed 15 and $30 \%$ of their ration as tanier corms had lower daily gains than those fed concentrate alone, these lower gains may be more economical.

About $180 \mathrm{~kg}$ of commercial concentrates, costing about $\$ 40.00$, is needed to grow pigs from weaning to a market weight of $55 \mathrm{~kg}$, which is preferred in Puerto Rico. Assuming that corms can substitute for $1 / 3$ of this feed, $60 \mathrm{~kg}$ of dry corms would be worth $\$ 13.20$ in terms of commerical feed. About $375 \mathrm{~kg}$ of corms are needed to provide $60 \mathrm{~kg}$ net dry matter, since $20 \%$ of the corms are lost in peeling. Thus, the feed value of corms would be about 3.52 cents $/ \mathrm{kg}$, for which the cost of mechanical or chemical peeling or of boiling must be deducted. Therefore, the not feed value of tanier corms to pigs would be about 2.82 cents $/ \mathrm{kg}$. Thus, $i$ ha of taniers, producing 24.7 metric tons of corms (which are now rasted), would have an additional value of about $\$ 696 /$ ha. The use of corms as pig feed by the small tropical farmer, who cannot afford concentrate alone, is also important.

\section{RESUMEN}

Se compararon diferentes alimentos basados en cormos (madres de yautía; Xanthosoma spp.) suplementados con distintos niveles de alimentos concentrados en la alimentación de cerdos. Se determinó que el cormo de yautía contiene aproximadamente $20 \%$ de materia seca y que se puede almacenar con cáscara en lugares secos sin refrigeración por períodos hasta de un año. Al mondarse mecánicamente con cuchillo o machete, el rendimiento del cormo fue de aproximadamente $80 \%$, mientras que al pelarse con una solución de lejía, fue de aproximadamente $70 \%$. El cormo ofrecido crudo sin cáscara, mondado mecánica o químicamente, no fue tan sabroso como cormos hervidos sin pelar. Los cormos mondados químicamente se congelaron y se almacenaron en bolsas plásticas, pero se deterioraron rápidamente si no se usaban al día después de deshelados.

Los cerdos alimentados exclusivamente con alimento concentrado lograron los mayores aumentos de peso y los que sólo recibieron cormos apenas lo aumentaron. Cuando los cormos suplieron entre el 30 y el $48 \%$ de la ración y fueron complementados con alimentos concentrados que contenían 16 ó $24 \%$ de proteína y además, 2 veces la cantidad normal de vitaminas, oligominerales y sal, el crecimiento y eficiencia de utilización fueron aproximadamente de 10 a $20 \%$ menores que el control a base de alimentos concentrados.

La mayor limitación para lograr inducir un consumo de cormos superior al 30-48\% de la ración parece ser la imposibilidad física de los cerdos en ingerir toda la materia seca requerida para un máximo crecimiento. 


\section{LITERATURE CITED}

1. Association of Official Agricultural Chemists, 1975, Official Methods of Analysis, 12th ed, Washington, D.C,

2. González, E., and Espinet, G. R., 1977, Análisis económico de la producción de yautías, Puerto Rico 1975, Esta. Exp. Agric. Univ. P. R. Bol. 249.

3. Greweling, T., 1962, An extractive procedure for the determination of total calcium, magnesium and potassium in plant tissue, J. Agric. Food Chem. 10: 132.

4. McDowell, L. R., Conrad, J. N., Thomas, J. E., and Marris, L. R., 1974, Tablas de Composición de Alimentos de América Latina, Instituto de Ciencias Alimenticias y Agropecuarias, Centro de Agricultura Tropical, Departamento de Ciencia Animal, Univ. de Fla., E.E.U.U.

5. National Research Council, 1973, Nutrient requirements of swine, 7th ed, Nat. Acad. Sci., Washington, D.C.

6. - 1969. Joint United States-Canadian Tables of Food Composition, Nat. Acad. Sci., Washington, D.C., Publ. 1684.

7. Pond, W. G., and Maner, J. H., 1974, Swine production in temperate and tropical environments, W. H. Freeman and Co., p. 295.

8. Rodríguez-Sosa, E. J., and González, M. A., 1977, Preparation of instant tanier (Xanthosoma sagittifolium) flakes, J. Agric. Univ. P.R. 61(1): 26-31.

9. Snedecor, G. W., and Cochran, W. G., 1967, Statistical Methods, 6th ed, Iowa State Univ. Press, Ames, Iowa. 